Correspondence

John R. W. Govan

john.r.w.govan@ed.ac.uk

Received 11 October 2002

Accepted 12 February 2003

\section{Lysogeny and bacteriophage host range within the Burkholderia cepacia complex}

\author{
Ross Langley, ${ }^{1}$ Dervla T. Kenna, ${ }^{1}$ Peter Vandamme, ${ }^{2}$ Rebecca Ure ${ }^{1}$ and \\ John R. W. Govan ${ }^{1}$ \\ ${ }^{1}$ Department of Medical Microbiology, University of Edinburgh, Teviot Place, Edinburgh EH8 9AG, UK \\ ${ }^{2}$ Laboratorium voor Mikrobiologie, Faculteit Wetenschappen, Universiteit Gent, K. L. Ledeganckstraat \\ 35, B-9000 Gent, Belgium
}

\begin{abstract}
The Burkholderia cepacia complex comprises a group of nine closely related species that have emerged as life-threatening pulmonary pathogens in immunocompromised patients, particularly individuals with cystic fibrosis or chronic granulomatous disease. Attempts to explain the genomic plasticity, adaptability and virulence of the complex have paid little attention to bacteriophages, particularly the potential contribution of lysogenic conversion and transduction. In this study, lysogeny was observed in 10 of 20 representative strains of the $B$. cepacia complex. Three temperate phages and five lytic phages isolated from soils, river sediments or the plant rhizosphere were chosen for further study. Six phages exhibited T-even morphology and two were lambda-like. The host range of individual phages, when tested against 66 strains of the $B$. cepacia complex and a representative panel of other pseudomonads, was not species-specific within the $B$. cepacia complex and, in some phages, included Burkholderia gladioli and Pseudomonas aeruginosa. These new data indicate a potential role for phages of the $B$. cepacia complex in the evolution of these soil bacteria as pathogens of plants, humans and animals, and as novel therapeutic agents.
\end{abstract}

\section{INTRODUCTION}

In the last decade, bacteria previously identified as Burkholderia cepacia sensu lato have become recognized as important human pathogens, and particularly as a cause of lifethreatening pulmonary infections in individuals with cystic fibrosis (CF) or chronic granulomatous disease (Govan et al., 1996; LiPuma, 1998; Jones et al., 2001; Mahenthiralingam et al., 2002). Concurrently, polyphasic taxonomic approaches revealed that $B$. cepacia sensu lato comprises at least nine phylogenetically related but genomically distinct species (genomovars) (Vandamme et al., 1997, 2003; Coenye et al., 2001). Known as the B. cepacia complex, the group currently comprises B. cepacia (previously genomovar I), Burkholderia multivorans (genomovar II), 'Burkholderia cenocepacia' (genomovar III), Burkholderia stabilis (genomovar IV), Burkholderia vietnamiensis (genomovar V), B. cepacia genomovar VI, Burkholderia ambifaria (genomovar VII), Burkholderia anthina (genomovar VIII) and Burkholderia pyrrocinia (genomovar IX). All species in the B. cepacia complex have been isolated from clinical specimens; however, the clinical significance of individual genomovars in human disease remains unclear. Approximately $90 \%$ of B. cepacia complex isolates cultured from CF patients belong to B. multivorans and 'B. cenocepacia' (Agodi et al., 2001; LiPuma et al., 2001;

Abbreviations: CF, cystic fibrosis; NBYE, nutrient broth with yeast extract.
Mahenthiralingam et al., 2002; Speert et al., 2002; Vandamme et al., 2003). These two species account for most episodes of epidemic spread in CF and non-CF patients (Holmes et al., 1999; Mahenthiralingam et al., 2002); ' $B$. cenocepacia' is also the species most associated with the rapid pulmonary decline known as cepacia syndrome, and with post-transplant mortality (Aris et al., 2001).

Most isolates of the B. cepacia complex exhibit high-level resistance to all major classes of antibiotics (Lewin et al., 1993; Pitt et al., 1996; Nzula et al., 2002). The B. cepacia complex is also one of the few groups of bacteria to exhibit intrinsic resistance to cationic antimicrobial peptides (Hancock, 1997). Some strains are susceptible in vitro to ceftazidime and meropenem, arguably the most potent 'anticepacia' agents; however, the majority of strains, including the highly transmissible 'B. cenocepacia' lineage ET12, are resistant to these agents (Lewin et al., 1993; Nzula et al., 2002).

All bacteria in the $B$. cepacia complex have large genomes (mean size approx. $8 \mathrm{Mbp}$ ), comprising multiple replicons that may contribute to genomic plasticity (Lessie et al., 1996; Wigley \& Burton 2000; Parke \& Gurian-Sherman, 2001; Mahenthiralingam et al., 2002). Ironically, the B. cepacia complex could be considered as both friend and foe, as some strains are highly effective as biopesticides in the control of plant fungal diseases and in bioremediation of contaminated 
soils (Holmes et al., 1998; Parke \& Gurian-Sherman, 2001). These dual roles raise important medical, agricultural and ecological issues (Govan et al., 1996, 2000; Govan \& Vandamme, 1998; Environmental Protection Agency, 2002), including the significance of horizontal gene transfer in assessment of the risk to humans of using these bacteria as biopesticides or in bioremediation (Holmes et al., 1998; LiPuma \& Mahenthiralingam, 1999; Govan et al., 2000; Parke \& Gurian-Sherman, 2001).

Attempts to explain the genomic plasticity, adaptability and virulence of the $B$. cepacia complex have paid little attention to the potential contribution of bacteriophages. In many pathogens, these bacterial viruses are recognized as important contributors to virulence, in the form of bacterial lysogens, or as vectors in horizontal gene transfer. Interest in the use of phage-induced bacterial lysis for therapeutic purposes was widespread in the 1920s, but declined with the arrival of the antibiotic era. However, as antibiotic resistance increasingly threatens standard therapies against bacterial infections, there is renewed interest in the antimicrobial properties of these highly specific agents (Pirisi, 2000; Sulakvelidze et al., 2001).

Little is known of the phages of the B. cepacia complex. Early reports on the ' $B$. cepacia' phages CP1 (Cihlar et al., 1978) and CP 75 (Matsumoto et al., 1986) predate the revision of B. cepacia taxonomy. However, a recent report from our laboratories described two transducing bacteriophages, NS1 and NS2, whose host range included the five genomovars (IV) that were known at the time, and also extended to Pseudomonas aeruginosa (Nzula et al., 2000). Lytic phages with an interspecies host range within the B. cepacia complex have also been reported in association with soil-borne strains of 'B. cenocepacia' (LiPuma et al., 2000). These results suggest that lysogenic conversion and transduction could play a role in the evolution of species of the B. cepacia complex as human pathogens, and indicate the need for further studies on the host range and properties of phages associated with the $B$. cepacia complex and related bacteria.

In this study, we investigated the prevalence of lysogeny within the nine current species of the B. cepacia complex and isolated lytic phages from natural habitats of these bacteria, including the plant rhizosphere. Our results show that the host range of the phage panel includes seven genomovars and, in the case of individual phages, is not genomovarspecific.

\section{METHODS}

Bacterial strains. The 66 strains of the B. cepacia complex used in this study are listed in Table 1 . The collection comprised environmental and clinical isolates belonging to genomovars I-V that were included in the B. cepacia strain panel (Mahenthiralingam et al., 2000a), and isolates representing the recently identified genomovars VI-IX (Coenye et al., 2001). Four isolates identified as Burkholderia ubonensis, a putative tenth genomovar of the B. cepacia complex (Vermis et al., 2002), were also included. Isolates were identified using recA RFLPs, whole-cell protein electrophoresis and DNA-DNA hybridization (Mahenthiral- ingam et al., 2000b; Coenye et al., 2001). In addition, 55 strains of related pseudomonad species were screened as potential phage hosts: $P$. aeruginosa (30 strains), Stenotrophomonas maltophilia $(n=11)$, Burkholderia caledonica $(n=1)$, Burkholderia gladioli $(n=2)$, Comamonas acidovorans $(n=2)$, Pseudomonas fluorescens $(n=2)$, Pseudomonas mendocina $(n=1)$, Pseudomonas stutzeri $(n=2)$, Pseudomonas putida $(n=1)$, Pseudomonas testosteroni $(n=1)$, Pseudomonas syringae pv. tabaci $(n=1)$ and Ralstonia pickettii $(n=1)$. Clonal relationships were excluded by PFGE fingerprinting using a Bio-Rad CHEF Mapper PFGE system (Butler et al., 1995).

Media. Bacteria were grown in nutrient broth with $0.5 \%$ yeast extract (NBYE) at $37^{\circ} \mathrm{C}$ in a shaking incubator. Soft overlay agar for phage experiments comprised Luria-Bertani (LB) broth with $0 \cdot 3 \%$ bacteriological agar (Difco). The nutrient agar used was Columbia agar base (39 $\mathrm{g} \mathrm{l}^{-1}$; Oxoid).

Isolation of lysogenic phages. Temperate phages were assayed and maintained as described previously (Nzula et al., 2000). Lysogeny was investigated using the following method: the 20 strains designated in Table 1 with the symbol $\dagger$ were prepared as saline suspensions (approx. $10^{6}$ c.f.u. $\mathrm{ml}^{-1}$ ), inoculated onto tryptone soy agar (TSA; Oxoid) using a multipoint inoculator and incubated at $30^{\circ} \mathrm{C}$ for $6 \mathrm{~h}$. Bacterial growth was inverted over chloroform vapour for $15 \mathrm{~min}$ and then allowed to air-dry for $15 \mathrm{~min}$. Soft agar overlays $(2.5 \mathrm{ml})$, inoculated with $100 \mu \mathrm{l}$ exponential-phase culture of each of the 20 strains, were layered over the original bacterial growth and allowed to set; the plates were incubated overnight at $37^{\circ} \mathrm{C}$. Phage plaques were identified in the overlay in the proximity of the original inoculum and used to prepare single-plaque preparations as follows: an agar plug containing a single phage plaque was removed using a sterile glass pipette, transferred to $10 \mathrm{ml}$ phage buffer $\left(10 \mathrm{mM}\right.$ Tris/HCl, $\mathrm{pH} 8.0 ; 10 \mathrm{mM} \mathrm{MgCl}_{2}$ ), vortexed for $30 \mathrm{~s}$, centrifuged at $3000 \mathrm{~g}$ for $30 \mathrm{~min}$ and filtered (pore size $0 \cdot 2 \mu \mathrm{m}$; Millipore).

Isolation of lytic environmental phage. The natural habitats of the $B$. cepacia complex include soils, river sediments and plants, particularly the plant rhizosphere (Fisher et al., 1993; Butler et al., 1995; Parke \& Gurian-Sherman, 2001). Therefore, 20 samples of soil, river sediment and rhizosphere (soil plus root material) were collected. The presence of phage was then investigated using a modification of the phage enrichment technique described by Weiss et al. (1994), as follows: approximately $10 \mathrm{~g}$ sample was suspended in $15 \mathrm{ml} \mathrm{LB}$ broth and dispersed by shaking in an orbital incubator for $30 \mathrm{~min}$ at $30^{\circ} \mathrm{C}$. After removal of soil particles by centrifugation $(4000 \mathrm{~g}$ for $20 \mathrm{~min}$ ), the supernatant was filter-sterilized (pore size $0.2 \mu \mathrm{m}$; Acrodisc) and $1 \mathrm{ml}$ aliquots were added to 15 sterile tubes. To each extract was added $25 \mu \mathrm{l}$ exponential-phase culture from one of 15 propagating strains chosen to represent the genomovars of the $B$. cepacia complex strain panel (Mahenthiralingam et al., 2000a), and the contents were incubated at $37^{\circ} \mathrm{C}$ overnight. The bacterial cells were removed by centrifugation ( $4000 \mathrm{~g}$ for $30 \mathrm{~min}$ ), the supernatant was membrane-filtered as before and $10 \mu \mathrm{l}$ filtrate was spotted onto single-layer lawns of the propagating strain. Phage plaques were identified after overnight incubation at $37^{\circ} \mathrm{C}$, and single-plaque stocks were prepared as described in the previous section.

High-titre phage preparations. High-titre phage preparations were prepared as follows: $100 \mu \mathrm{l}$ single-plaque preparation, containing approximately $10^{5}$ p.f.u. $\mathrm{ml}^{-1}$, was added to $2.5 \mathrm{ml}$ soft nutrient agar, previously seeded with $100 \mu$ l exponential-phase culture of the propagating strain. The mixture was then overlaid on nutrient agar and allowed to set. After $18 \mathrm{~h}$ at $37^{\circ} \mathrm{C}$, overlays showing semi-confluent lysis were transferred into $10 \mathrm{ml}$ phage buffer. The lysate was then vortexed and centrifuged at $3200 \mathrm{~g}$ for $30 \mathrm{~min}$ and the supernatant was membrane-filtered. Phage titres were determined, as p.f.u. $\mathrm{ml}^{-1}$, by 
incorporating $100 \mu \mathrm{l}$ host bacteria (exponential-phase NBYE culture) and $100 \mu \mathrm{l}$ phage stock in $2.5 \mathrm{ml}$ soft agar overlay, and lytic plaques were enumerated after $18 \mathrm{~h}$ incubation at $37^{\circ} \mathrm{C}$. Stock preparations were maintained at $4{ }^{\circ} \mathrm{C}$.

Host range of phages. Stock phage preparations were diluted in phage buffer to approximately $10^{8}$ p.f.u. $\mathrm{ml}^{-1}$ against the propagating strain, and $10 \mu \mathrm{l}$ was spotted onto single-layer lawns (prepared from exponential-phase NBYE cultures) of potential host bacteria. Lytic activity was recorded after $24 \mathrm{~h}$ at $37^{\circ} \mathrm{C}$ on a scale ranging from $<10$ plaques $(+)$ to confluent lysis $(+++)$ (Table 1$)$.

Electron microscopy. Stock phage preparations (approx. $10^{8}$ p.f.u. $\mathrm{ml}^{-1}$ ) were centrifuged at $100000 \mathrm{~g}$ for $1 \mathrm{~h}$. Phage pellets were resuspended in $1 \mathrm{M}$ ammonium acetate, negatively stained with $2 \%(\mathrm{w} / \mathrm{v})$ potassium phosphotungstate solution $(\mathrm{pH} 7 \cdot 0)$ and examined with a Hitachi model HU-12A transmission electron microscope.

Phage DNA extraction and RFLP profiling. In preparation for DNA extraction, high-titre phage stocks (containing at least $10^{10}$ p.f.u. $\mathrm{ml}^{-1}$ ) were prepared using soft agar overlays, as described above. DNA was extracted from $10 \mathrm{ml}$ phage stock using the Wizard Lambda preparation DNA purification system in conjunction with the Vac-Man laboratory vacuum manifold (both from Promega). Extracted DNA was eluted in sterile distilled water and stored at $-20{ }^{\circ} \mathrm{C}$. DNA quality was assessed on an E-gel pre-cast $0 \cdot 8 \%$ agarose gel (Invitrogen Life Technologies). In cases where DNA was not of sufficient quality for DNA restriction, purification was performed using the PCR protocol from the QIAquick gel extraction kit (Qiagen). Purified DNA was eluted in $30 \mu \mathrm{l}$ elution buffer and stored at $4{ }^{\circ} \mathrm{C}$. To determine genome size and to confirm that the phages were different from one another, approximately $1 \mu \mathrm{g}$ DNA was restricted using $10 \mathrm{U}$ HindIII (Promega), incubated for $3 \mathrm{~h}$ at $37^{\circ} \mathrm{C}$ and visualized on $0 \cdot 6 \% 0 \cdot 5 \times$ TBE agarose gel alongside $1 \mu$ l ReadyLoad Lambda DNA/HindIII fragments (Invitrogen Life Technologies).

\section{RESULTS}

\section{Lysogeny}

Of the 20 strains of the B. cepacia complex that were investigated, 10 strains [ATCC $25416^{\mathrm{T}}$ and ATCC 17759 (genomovar I); C3161 ${ }^{\mathrm{T}}, \mathrm{C} 1576, \mathrm{C} 1962$ and C3163 (B. multivorans); J2315 ${ }^{\mathrm{T}}, \mathrm{C} 3166$ and $\mathrm{C} 3170$ ('B. cenocepacia'); and C3174 (B. stabilis)] were found to be lysogenized. These provided 14 temperate phages (DK1-DK4 and MM1MM10) for further study.

\section{Isolation of environmental phages}

Five virulent phages, JB1, JB3, JB5, RL1c and RL2, were isolated from soils and from the rhizosphere of various plants (Table 2). Most positive samples included decayed plant material collected from moist environments, but phages were also isolated from dry soils.

\section{Host range of B. cepacia complex phages NS1, NS2 and newly isolated phages}

To confirm that distinct phages were being accumulated and investigated, we determined the host range of the 19 phages against a preliminary bacterial panel comprising the 20 isolates of the B. cepacia complex that were used in the lysogeny screen, and also the HindIII RFLP profile (and hence an approximate genome size; Table 2). With the exception of phages JB3, DK2 and DK3, the genomes of the B. cepacia complex phages were within the range $40-48 \mathrm{kbp}$ (Table 2). If several phages shared the same host range and RFLP profile, only one phage was used for further study. An exception was made for phages RL1c and RL1t, which shared the same host range and RFLP profile but produced different plaque morphologies: clear plaques associated with virulent phage (RL1c) or turbid, temperate phage plaques (RL1t). Similar host ranges and RFLP profiles were observed with the temperate phages DK2 and DK3, which had respectively been isolated from 'B. cenocepacia' C3166 and B. stabilis C3174. As previously observed for NS1 and NS2, none of the newly identified phages was inactivated by treatment with chloroform. In addition, no evidence of bacteriocin activity was found during the search for B. cepacia complex phages.

The host range of phages NS1, NS2 and eight novel phages (JB1, JB3, JB5, DK1, DK3, RL1c, RL1t and RL2) was then determined against an enlarged panel of 66 isolates of the B. cepacia complex and 55 isolates representing other pseudomonads. The host range of individual phages included multiple species of the B. cepacia complex. Collectively, the host range of the phage panel included seven of the presently recognized B. cepacia genomovar species; no phage activity was detected against the single representatives of $B$. cepacia genomovar VI or B. ambifaria (Table 1). However, within each $B$. cepacia species, there was wide variation in susceptibility to an individual phage. B. multivorans appeared to be least susceptible to phages investigated in this study: of nine B. multivorans strains examined as potential phage hosts, only strain C2775 showed susceptibility. As observed previously for NS1 and NS2, the host range of some of the phages was not restricted to the B. cepacia complex. $P$. aeruginosa strains $\mathrm{C} 1546$ and $\mathrm{J} 2852$ were susceptible to phage JB3, and B. gladioli strain C3654 was susceptible to phages NS2, DK1, RL1c, RL1t and JB5.

\section{Electron microscopy}

In accordance with previous studies on phages NS1 and NS2 (Nzula et al., 2000), electron microscopy revealed the novel phages JB1, JB5, DK2/DK3, RL1c/RL1t and RL2 to be morphologically T-even-like phages, with hexagonal heads and contractile tails of variable length. In contrast, phages JB3 and DK1 were lambda-like, with hexagonal heads and flexuous, non-contractile tails.

\section{DISCUSSION}

This study confirmed that lysogeny is relatively common in isolates of the B. cepacia complex and demonstrated the presence of virulent $B$. cepacia complex phages in the natural habitats of these bacteria. In agreement with previous observations of phages NS1 and NS2 (Nzula et al., 2000), the host range of the newly isolated phages was not genomovar-specific and, in some phages (for example JB1), it included the majority of B. cepacia complex species. This broad host range, which in some phages extended to the 
Table 1. Host range of bacteriophages within the $B$. cepacia complex

- , Lack of sensitivity to phage;,$+<10$ plaques at phage inoculation site;,$++>10$ plaques at phage inoculation site; +++ , confluent lysis at phage inoculation site.

\begin{tabular}{|c|c|c|c|c|c|c|c|c|c|}
\hline Strain & $\mathrm{JB1}$ & JB3 & JB5 & DK1 & DK3 & NS1 & NS2 & RL1t/RL1c & RL2 \\
\hline \multicolumn{10}{|l|}{ B. серасіа } \\
\hline $\operatorname{ATCC} 25416^{\mathrm{T}}\left(=\mathrm{LMG} 1222^{\mathrm{T}}\right)^{*} \dagger$ & - & - & - & - & - & - & - & - & - \\
\hline C2970 (= LMG 17997) & + & - & + & - & - & + & + & +++ & - \\
\hline C3159 (= LMG 18821)† & - & - & - & - & - & - & - & - & - \\
\hline ATCC $17759(=\text { LMG 2161 })^{*} \dagger$ & - & - & - & - & +++ & - & - & - & - \\
\hline \multicolumn{10}{|l|}{ B. multivorans } \\
\hline $\mathrm{C} 2775$ & - & + & - & + & + & + & + & +++ & - \\
\hline C3161 $1^{\mathrm{T}}\left(=\mathrm{LMG} 13010^{\mathrm{T}}\right)^{*} \dagger$ & - & - & - & - & - & - & - & - & - \\
\hline C3162 (= LMG 18825) $\dagger$ & - & - & - & - & - & - & - & - & - \\
\hline C3163 $(=\text { LMG } 18824)^{*} \dagger$ & - & - & - & - & - & - & - & - & - \\
\hline C3164 (= LMG 18823)† & - & - & - & - & - & - & - & - & - \\
\hline ATCC 17616 (= LMG 17588) & - & - & - & - & - & - & - & - & - \\
\hline C1962 (= LMG 16665)*† & - & - & - & - & - & - & - & - & - \\
\hline $\mathrm{C} 1576(=\mathrm{LMG} 16660)^{*} \dagger$ & - & - & - & - & - & - & - & - & - \\
\hline $\mathrm{C} 3160(=\mathrm{LMG} 18822) \dagger$ & - & - & - & - & - & - & - & - & - \\
\hline \multicolumn{10}{|l|}{ 'B. сепосерасіа' } \\
\hline J415 (= LMG 16654) & - & - & - & + & - & - & + & - & +++ \\
\hline $\mathrm{J} 2315^{\mathrm{T}}\left(=\mathrm{LMG} 16656^{\mathrm{T}}\right)^{*} \dagger$ & - & - & - & - & - & - & +++ & - & - \\
\hline C1394 (= LMG 16659) & - & - & - & - & + & - & + & - & ++ \\
\hline $\mathrm{J} 2956$ & +++ & +++ & +++ & - & +++ & - & - & + & +++ \\
\hline C2836 & - & - & + & - & - & + & + & - & ++ \\
\hline C3165 (= LMG 18826) & - & - & - & - & - & - & + & - & - \\
\hline C3166 $(=\text { LMG } 18863)^{*} \dagger$ & - & - & - & - & - & + & + & - & - \\
\hline C3167 (= LMG 18827)† & - & - & - & - & - & - & - & - & - \\
\hline C3168 (= LMG 18828)† & - & - & - & - & - & - & - & - & - \\
\hline C3169 (= LMG 18829) & +++ & +++ & ++ & +++ & +++ & ++ & ++ & - & +++ \\
\hline C3170 (= LMG 18830)* & - & - & - & - & - & + & + & - & +++ \\
\hline ATCC 17765 (= LMG 18832) & ++ & - & + & +++ & - & - & + & + & - \\
\hline \multicolumn{10}{|l|}{ B. stabilis } \\
\hline $\mathrm{C} 3171^{\mathrm{T}}\left(=\mathrm{LMG} 14294^{\mathrm{T}}\right)$ & - & - & - & - & - & + & - & +++ & - \\
\hline C3172 (= LMG 18870) & + & - & - & - & - & - & - & - & - \\
\hline C3173 (= LMG 18888) $\dagger$ & - & - & - & - & + & - & - & - & - \\
\hline C3174 $(=\text { LMG } 14086)^{*} \dagger$ & - & - & - & - & - & - & - & - & - \\
\hline \multicolumn{10}{|l|}{ B. vietnamiensis } \\
\hline C2978 (= LMG 16232) † & - & - & - & - & - & + & + & +++ & - \\
\hline C3175 (= LMG 18835)† & - & - & + & - & - & - & - & - & - \\
\hline C3176 (= LMG 18836) $\dagger$ & - & - & - & - & - & - & + & - & - \\
\hline $\mathrm{C} 3177^{\mathrm{T}}(=\mathrm{LMG} 10929) \dagger$ & +++ & - & +++ & + & +++ & - & - & + & +++ \\
\hline \multicolumn{10}{|l|}{ Genomovar VI } \\
\hline E12 & - & - & - & - & - & - & - & - & - \\
\hline \multicolumn{10}{|l|}{ B. ambifaria } \\
\hline $\mathrm{J} 2742^{\mathrm{T}}\left(=\mathrm{LMG} 19182^{\mathrm{T}}\right)$ & - & - & - & - & - & - & - & - & - \\
\hline \multicolumn{10}{|l|}{ B. anthina } \\
\hline $\mathrm{J} 2552(=\mathrm{LMG} 16670)$ & - & - & - & - & - & - & - & - & - \\
\hline $\mathrm{J} 2553$ & - & - & - & - & - & - & - & - & - \\
\hline $\mathrm{J} 2863$ (= LMG 20980) & - & - & - & - & - & - & - & - & - \\
\hline $\mathrm{J} 2927$ & - & - & - & - & - & - & - & - & - \\
\hline $\mathrm{J} 2928$ & - & - & - & - & - & - & - & - & - \\
\hline $\mathrm{J} 2941$ & - & - & - & - & - & - & - & - & - \\
\hline $\mathrm{J} 2943$ & - & - & - & - & - & - & - & - & - \\
\hline $\mathrm{J} 2944$ & - & - & - & - & - & - & - & - & - \\
\hline
\end{tabular}

(continued overleaf) 
Table 1. cont.

\begin{tabular}{|c|c|c|c|c|c|c|c|c|c|}
\hline Strain & JB1 & JB3 & JB5 & DK1 & DK3 & NS1 & NS2 & RL1t/RL1c & RL2 \\
\hline $\mathrm{J} 2945$ & - & - & - & - & - & - & - & - & - \\
\hline J2946 & - & - & - & - & - & - & - & - & - \\
\hline J2949 & - & - & - & - & - & - & - & - & - \\
\hline $\mathrm{J} 2950$ & - & - & - & - & - & - & - & - & - \\
\hline J2951 & +++ & - & +++ & - & - & + & - & - & +++ \\
\hline $\mathrm{J} 2862$ & - & - & - & - & - & - & - & - & +++ \\
\hline C1658 (= LMG 20982) & +++ & + & +++ & - & - & - & - & - & - \\
\hline C1765 (= LMG 20983) & +++ & + & ++ & - & - & + & - & ++ & - \\
\hline \multicolumn{10}{|l|}{ B. pyrrocinnia } \\
\hline $\mathrm{J} 2536$ & - & - & - & - & - & - & - & - & - \\
\hline $\mathrm{J} 2542$ & - & - & - & - & - & - & - & - & - \\
\hline C1469 & - & - & - & - & - & - & - & - & - \\
\hline C3909 & ++ & - & ++ & - & - & - & - & - & - \\
\hline C3918 & + & - & + & + & - & + & - & - & +++ \\
\hline C3928 & - & - & - & - & - & - & - & - & - \\
\hline C3930 & +++ & - & +++ & - & - & +++ & - & - & ++ \\
\hline C3993 & +++ & - & +++ & - & - & - & - & - & ++ \\
\hline C3995 & +++ & - & +++ & - & - & - & - & - & ++ \\
\hline C3997 & + & - & - & - & - & - & - & - & - \\
\hline \multicolumn{10}{|l|}{ B. ubonensis } \\
\hline E26 & - & - & - & - & - & - & - & - & ++ \\
\hline E27 & - & - & - & - & - & - & - & - & - \\
\hline E571 & - & - & - & - & - & - & - & - & - \\
\hline E551 & + & ++ & - & - & - & - & - & - & - \\
\hline \multicolumn{10}{|l|}{ Genomovar unclassifiable } \\
\hline $\mathrm{J} 2540$ (= LMG 16672) & - & - & - & - & - & + & + & - & - \\
\hline
\end{tabular}

${ }^{\star}$ Lysogenic strains.

$\dagger$ Strains used in lysogeny experiments.

Table 2. Phage genome size, plaque morphology and source

\begin{tabular}{|lcll|}
\hline Phage & $\begin{array}{c}\text { Genome size } \\
(\mathbf{b p})\end{array}$ & \multicolumn{1}{c|}{ Source } & \multicolumn{1}{c|}{ Plaque morphology } \\
& 40000 & Soil, the Caribbean & $\begin{array}{l}\text { Turbid plaques, variable size }(0 \cdot 5-1 \mathrm{~mm} \text { in diameter }) \\
\text { JB1 }\end{array}$ \\
JB3 & 34000 & Plant rhizosphere, UK & Clear plaques $(1 \mathrm{~mm}$ in diameter $)$ \\
JB5 & 40000 & Plant rhizosphere, UK & Turbid plaques, variable size $(0 \cdot 5-1 \mathrm{~mm}$ in diameter $)$ \\
DK1 & 45900 & Lysogeny & Turbid plaques, variable size $(0 \cdot 5-1 \mathrm{~mm}$ in diameter $)$ \\
DK2/DK3 & 29300 & Lysogeny & Turbid plaques $(1 \mathrm{~mm}$ in diameter $)$ \\
NS1 & $48000 \dagger$ & Lysogeny & Turbid plaques $(0 \cdot 5-1 \mathrm{~mm}$ in diameter $)$ \\
NS2 & $48000 \dagger$ & Lysogeny & Semi-clear plaques, variable size $(0 \cdot 5-1 \mathrm{~mm}$ in diameter $)$ \\
RL1c/RL1t & 44300 & Plant rhizosphere, UK & RL1c, clear plaques $(1 \mathrm{~mm}$ in diameter); RL1t, turbid \\
& & & plaques (1 mm in diameter $)$ \\
RL2 & 40000 & Pond sediment, UK & Semi-clear plaques, variable size $(0 \cdot 5-1 \mathrm{~mm}$ in diameter $)$ \\
\hline
\end{tabular}

${ }^{\star}$ Plaque morphology on propagating strains (i.e. strain J2956 for phages JB1, JB3 and JB5; strain C3169 for phages DK1, DK3, NS2 and RL2; strain C2978 for phages RL1c/RL1t; strain C3166 for phage NS1).

$\dagger$ Data from Nzula et al. (2000). 
related pseudomonads $P$. aeruginosa and $B$. gladioli, is interesting. With the exception of unusual phages such as the plasmid-like 'phasmid' P4 (Gutmann et al., 1990), the host range of most phages is species-specific. Lack of bacteriocin activity in our study could be explained by the techniques and conditions used and the low prevalence of bacteriocinogeny in B. cepacia sensu lato (Govan \& Harris, 1985).

A broad host range for $B$. cepacia complex phages could contribute to the genomic plasticity of these bacteria, and their evolution from highly metabolically active soil saprophytes to plant and human pathogens and, recently, also animal pathogens (Berriatua et al., 2001). Lysogenic conversion and transduction are important processes by which chromosomal host genes can be acquired and exchanged between bacteria. We have previously demonstrated in vitro transfer of antibiotic-resistance genes between B. vietnamensis strains by phages NS1 and NS2 (Nzula et al., 2000).

As reported for Shigella flexneri (Allison \& Verma, 2000), prophages may contribute to $\mathrm{O}$-antigen modification in the B. cepacia complex (Kenna et al., 2003), and to the role of B. cepacia complex LPS as a potent virulence determinant (Shaw et al., 1995; Hughes et al., 1997). Opportunities for transduction and lysogenic conversion would exist not only in natural environments shared by various $B$. cepacia complex species and related bacteria, but also in CF airway secretions, where mixed infections are frequent and bacterial populations can reach densities in excess of $10^{9}$ c.f.u. $\mathrm{ml}^{-1}$. Based on a close taxonomic relationship and shared insertion sequences and environmental habitats, we were particularly keen to test the phage panel against isolates of Burkholderia pseudomallei, the causative agent of melioidosis and a potential agent for bioterrorism (Mack \& Titball, 1998). In collaboration with Dr Ty Pitt (PHLS, Colindale, London, UK), only phage NS2 was found to be active, lysing 13 of $40 \mathrm{~B}$. pseudomallei strains tested (unpublished results). The potential importance of broad-host-range phages such as NS2 is also suggested by recent reports of $B$. pseudomallei infection in CF patients (including coinfection with B. cepacia) following travel to Thailand, where melioidosis is endemic (Schulin \& Steinmetz, 2001; Visca et al., 2001).

Further studies are required to determine the transducing potential and other biological properties (e.g. nucleic acid content and bacterial receptors) of the B. cepacia complex phages that were accumulated in this study. Meanwhile, several preliminary observations merit comment. The shared host range and RFLP profiles of the temperate phages DK2 and DK3, respectively isolated from strains of 'B. cenocepacia' and $B$. stabilis, suggest that integration of the same phage can occur in different species of the B. cepacia complex. While the presence of multiple prophages within a single strain is common in $P$. aeruginosa (Holloway et al., 1960), we found no evidence of polylysogeny during our investigation of $B$. cepacia complex phages. The variable plaque morphology exhibited by the environmental phages RL1c and RL1t is interesting and, to our knowledge, has not been reported previously for $B$. cepacia complex phages.

The relative lack of susceptibility of $B$. multivorans to the phage panel was interesting. Taken together, B. multivorans and 'B. cenocepacia' account for almost $90 \%$ of clinical isolates of the B. cepacia complex; however, in contrast to 'B. cenocepacia', B. multivorans is rarely isolated from natural environments (Bevivino et al., 2002; authors' unpublished data). In our study, of nine B. multivorans strains tested, only one (C2775) exhibited phage susceptibility. However, this resistance may be misleading, as a recent study in our laboratories identified a novel $B$. cepacia complex phage (RU2) from soil, which plates on B. multivorans C3164 and also on three other $B$. cepacia complex isolates that are resistant to the primary phage panel (Table 1), namely J2552 and J2553 (both B. anthina) and E571 (B. ubonensis).

Whole-genome sequencing of bacteria provides increasing evidence for widespread exchange of chromosomal genes and other extrachromosomal elements, mediated by phages. Thus, analyses following the recent sequencing and annotation of 'B. cenocepacia' $\mathrm{J} 2315^{\mathrm{T}}$ (= LMG $16656^{\mathrm{T}}=\mathrm{NCTC}$ $13227^{\mathrm{T}}$; http://www.sanger.ac.uk/Projects/B_cepacia/) are keenly awaited. In relation to the issue of multiple lysogeny in the B. cepacia complex, we performed a BLAST search of the provisional $\mathrm{J} 2315^{\mathrm{T}}$ genome sequence and found evidence of a single prophage. If confirmed, this would be an interesting result as, in this study and in a more extensive search for lysogeny in $\mathrm{J} 2315^{\mathrm{T}}$, we isolated only one temperate phage, DK4 (authors' unpublished data). The availability of broadhost-range phages complements the panel of $B$. cepacia complex strains (Mahenthiralingam et al., 2000a) and should facilitate future research on these highly adaptable and increasingly important bacteria. Furthermore, in addition to the established therapeutic use of lytic phages, phageencoded lytic enzymes may provide novel therapeutic agents against B. cepacia complex infections (Schuch et al., 2002), for which there are few antibiotic options at present (Nzula et al., 2002).

\section{ACKNOWLEDGEMENTS}

This study was supported by grants from the UK Cystic Fibrosis Trust (R. L., D. K. and J. R. W. G.) and the Fund for Scientific Research - Flanders (P. V.). R. U. was the recipient of a Gruss Summer Studentship. The authors are most grateful to Dr Ty Pitt (PHLS, Colindale, London) for advice and for testing the phages against a panel of B. pseudomallei strains. The authors would also like to thank Mr Steve Mitchell for his assistance with electron microscopy.

\section{REFERENCES}

Agodi, A., Mahenthiralingam, E., Barchitta, M., Gianninò, V., Sciacca, A. \& Stefani, S. (2001). Burkholderia cepacia complex infection in Italian patients with cystic fibrosis: prevalence, epidemiology, and genomovar status. J Clin Microbiol 39, 2891-2896. 
Allison, G. E. \& Verma, N. K. (2000). Serotype-converting bacteriophages and $\mathrm{O}$-antigen modification in Shigella flexneri. Trends Microbiol 8, 17-23.

Aris, R. M., Routh, J. C., LiPuma, J. J., Heath, D. G. \& Gilligan, P. H. (2001). Lung transplantation for cystic fibrosis patients with Burkholderia cepacia complex. Survival linked to genomovar type. Am J Respir Crit Care Med 164, 2102-2106.

Berriatua, E., Ziluaga, I., Miguel-Virto, C., Uribarren, P., Juste, R., Laevens, S., Vandamme, P. \& Govan, J. R. W. (2001). Outbreak of subclinical mastitis in a flock of dairy sheep associated with Burkholderia cepacia complex infection. J Clin Microbiol 39, 990-994.

Bevivino, A., Dalmastri, C., Tabacchioni, S., Chiarini, L., Belli, M. L., Piana, S., Materazzo, A., Vandamme, P. \& Manno, G. (2002). Burkholderia cepacia complex bacteria from clinical and environmental sources in Italy: genomovar status and distribution of traits related to virulence and transmissibility. J Clin Microbiol 40, 846-851.

Butler, S. L., Doherty, C. J., Hughes, J. E., Nelson, J. W. \& Govan, J. R. W. (1995). Burkholderia cepacia and cystic fibrosis: do natural environments present a potential hazard? J Clin Microbiol 33, 1001-1004.

Cihlar, R. L., Lessie, T. G. \& Holt, S. C. (1978). Characterization of bacteriophage $\mathrm{CP} 1$, an organic solvent sensitive phage associated with Pseudomonas cepacia. Can J Microbiol 24, 1404-1412.

Coenye, T., Vandamme, P., Govan, J. R. W. \& LiPuma, J. J. (2001). Taxonomy and identification of the Burkholderia cepacia complex. J Clin Microbiol 39, 3427-3436.

Environmental Protection Agency (2002). Burkholderia cepacia complex: proposed significant new use rule. Fed Regist 67, 1179-1186.

Fisher, M. C., LiPuma, J. J., Dasen, S. E., Caputo, G. C., Mortensen, J. E., McGowan, K. L. \& Stull, T. L. (1993). Source of Pseudomonas cepacia: ribotyping of isolates from patients and from the environment. J Pediatr 123, 745-747.

Govan, J. R. W. \& Harris, G. (1985). Typing of Pseudomonas cepacia by bacteriocin susceptibility and production. J Clin Microbiol 22, 490-494.

Govan, J. R. W. \& Vandamme, P. (1998). Agricultural and medical microbiology: a time for bridging gaps. Microbiology 144, 2373-2375.

Govan, J. R. W., Hughes, J. E. \& Vandamme, P. (1996). Burkholderia cepacia: medical, taxonomic and ecological issues. J Med Microbiol 45, 395-407.

Govan, J. R. W., Balandreau, J. \& Vandamme, P. (2000). Burkholderia cepacia - friend and foe. ASM News 66, 124-125.

Gutmann, L., Agarwal, M., Arthur, M., Campanelli, C. \& Goldstein, R. (1990). A phasmid shuttle vector for the cloning of complex operons in Salmonella. Plasmid 23, 42-58.

Hancock, R. E. W. (1997). Peptide antibiotics. Lancet 349, 418-422.

Holloway, B. W., Egan, J. B. \& Monk, M. (1960). Lysogeny in Pseudomonas aeruginosa. Aust J Exp Biol Med Sci 38, 321-329.

Holmes, A., Govan, J. \& Goldstein, R. (1998). Agricultural use of Burkholderia (Pseudomonas) cepacia: a threat to human health? Emerg Infect Dis 4, 221-227.

Holmes, A., Nolan, R., Taylor, R., Finley, R., Riley, M., Jiang, R.-Z., Steinbach, S. \& Goldstein, R. (1999). An epidemic of Burkholderia cepacia transmitted between patients with and without cystic fibrosis. $J$ Infect Dis 179, 1197-1205.

Hughes, J. E, Stewart, J., Barclay, G. R. \& Govan, J. R. W. (1997). Priming of neutrophil respiratory burst activity by lipopolysaccharide from Burkholderia cepacia. Infect Immun 65, 4281-4287.

Jones, A. M., Dodd, M. E. \& Webb, A. K. (2001). Burkholderia cepacia: current clinical issues, environmental controversies and ethical dilemmas. Eur Respir J 17, 295-301.

Kenna, D. T., Barcus, V. A., Langley, R. J., Vandamme, P. \& Govan,
J. R. W. (2003). Lack of correlation between O-serotype, bacteriophage susceptibility and genomovar status in the Burkholderia cepacia complex. FEMS Immunol Med Microbiol 35, 87-92.

Lessie, T. G., Hendrickson, W., Manning, B. D. \& Devereux, R. (1996). Genomic complexity and plasticity of Burkholderia cepacia. FEMS Microbiol Lett 144, 117-128.

Lewin, C., Doherty, C. \& Govan, J. (1993). In vitro activities of meropenem, PD 127391, PD 131628, ceftazidime, chloramphenicol, cotrimoxazole, and ciprofloxacin against Pseudomonas cepacia. Antimicrob Agents Chemother 37, 123-125.

LiPuma, J. J. (1998). Burkholderia cepacia. Management issues and new insights. Clin Chest Med 19, 473-486.

LiPuma, J. J. \& Mahenthiralingam, E. (1999). Commercial use of Burkholderia cepacia. Emerg Infect Dis 5, 305-306.

LiPuma, J. J., Mahenthiralingam, E., Mark, G. L. \& Gonzalez, C. F. (2000). Isolation of soil-borne genomovar III Burkholderia cepacia and lytic phages with interspecies host range. Pediatr Pulmonol S20, 288-289 (abstract).

LiPuma, J. J., Spilker, T., Gill, L. H., Campbell, P. W., III, Liu, L. \& Mahenthiralingam, E. (2001). Disproportionate distribution of Burkholderia cepacia complex species and transmissibility markers in cystic fibrosis. Am J Respir Crit Care Med 164, 92-96.

Mack, K. \& Titball, R. W. (1998). The detection of insertion sequences within the human pathogen Burkholderia pseudomallei which have been identified previously in Burkholderia cepacia. FEMS Microbiol Lett 162, 69-74.

Mahenthiralingam, E., Coenye, T., Chung, J. W., Speert, D. P., Govan, J. R. W., Taylor, P. \& Vandamme, P. (2000a). Diagnostically and experimentally useful panel of strains from the Burkholderia cepacia complex. J Clin Microbiol 38, 910-913.

Mahenthiralingam, E., Bischof, J., Byrne, S. K., Radomski, C., Davies, J. E., Av-Gay, Y. \& Vandamme, P. (2000b). DNA-based diagnostic approaches for identification of Burkholderia cepacia complex, Burkholderia vietnamiensis, Burkholderia multivorans, Burkholderia stabilis, and Burkholderia cepacia genomovars I and III. J Clin Microbiol 38, 3165-3173.

Mahenthiralingam, E., Baldwin, A. \& Vandamme, P. (2002). Burkholderia cepacia complex infection in patients with cystic fibrosis. J Med Microbiol 51, 533-538.

Matsumoto, H., Itoh, Y., Ohta, S. \& Terawaki, Y. (1986). A generalized transducing phage of Pseudomonas cepacia. J Gen Microbiol 132, 2583-2586.

Nzula, S., Vandamme, P. \& Govan, J. R. W. (2000). Sensitivity of the Burkholderia cepacia complex and Pseudomonas aeruginosa to transducing bacteriophages. FEMS Immunol Med Microbiol 28, 307-312.

Nzula, S., Vandamme, P. \& Govan, J. R. W. (2002). Influence of taxonomic status on the in vitro antimicrobial susceptibility of the Burkholderia cepacia complex. J Antimicrob Chemother 50, 265-269.

Parke, J. L. \& Gurian-Sherman, D. (2001). Diversity of the Burkholderia cepacia complex and implications for risk assessment of biological control strains. Annu Rev Phytopathol 39, 225-258.

Pirisi, A. (2000). Phage therapy - advantages over antibiotics? Lancet $356,1418$.

Pitt, T. L., Kaufmann, M. E., Patel, P. S., Benge, L. C. A., Gaskin, S. \& Livermore, D. M. (1996). Type characterisation and antibiotic susceptibility of Burkholderia (Pseudomonas) cepacia isolates from patients with cystic fibrosis in the United Kingdom and the Republic of Ireland. J Med Microbiol 44, 203-210.

Schuch, R., Nelson, D. \& Fischetti, V. A. (2002). A bacteriolytic agent that detects and kills Bacillus anthracis. Nature 418, 884-889. 
Schulin, T. \& Steinmetz, I. (2001). Chronic melioidosis in a patient with cystic fibrosis. J Clin Microbiol 39, 1676-1677.

Shaw, D., Poxton, I. R. \& Govan, J. R. W. (1995). Biological activity of Burkholderia (Pseudomonas) cepacia lipopolysaccharide. FEMS Immunol Med Microbiol 11, 99-106.

Speert, D. P., Henry, D., Vandamme, P., Corey, M. \& Mahenthiralingam, E. (2002). Epidemiology of Burkholderia cepacia complex in patients with cystic fibrosis, Canada. Emerg Infect Dis 8, 181-187.

Sulakvelidze, A., Alavidze, Z. \& Morris, J. G., Jr (2001). Bacteriophage therapy. Antimicrob Agents Chemother 45, 649-659.

Vandamme, P., Holmes, B., Vancanneyt, M. \& 8 other authors (1997). Occurrence of multiple genomovars of Burkholderia cepacia in cystic fibrosis patients and proposal of Burkholderia multivorans sp. nov. Int $J$ Syst Bacteriol 47, 1188-1200.
Vandamme, P., Holmes, B., Coenye, T., Goris, J., Mahenthiralingam, E., LiPuma, J. J. \& Govan, J. R. W. (2003). Burkholderia cenocepacia sp. nov. - a new twist to an old story. Res Microbiol 154, 91-96.

Vermis, K., Vandekerckhove, C., Nelis, H. J. \& Vandamme, P. A. R. (2002). Evaluation of restriction fragment length polymorphism analysis of $16 \mathrm{~S}$ rDNA as a tool for genomovar characterisation within the Burkholderia cepacia complex. FEMS Microbiol Lett 214, 1-5.

Visca, P., Cazzola, G., Petrucca, A. \& Braggion, C. (2001). Travelassociated Burkholderia pseudomallei infection (melioidosis) in a patient with cystic fibrosis: a case report. Clin Infect Dis 32, E15-E16.

Weiss, B. D., Capage, M. A., Kessel, M. \& Benson, S. A. (1994). Isolation and characterization of a generalized transducing phage for Xanthomonas campestris pv. campestris. J Bacteriol 176, 3354-3359.

Wigley, P. \& Burton, N. F. (2000). Multiple chromosomes in Burkholderia cepacia and $B$. gladioli and their distribution in clinical and environmental strains of B. cepacia. J Appl Microbiol 88, 914-918. 